\title{
Data Management Oversight Documentation
}

National Cancer Institute

\section{Source}

National Cancer Institute. Data Management Oversight Documentation. NCI Thesaurus.

Code C115683.

Records detailing the operating procedures for the acquisition, validation, storage, protection, and processing of data in a clinical trial. 